Article

\title{
Evaluation of Biofilm Formation and Prevalence of Multidrug-Resistant Strains of Staphylococcus epidermidis Isolated from Neonates with Sepsis in Southern Poland
}

\author{
Iwona Skiba-Kurek $^{1}{ }^{\mathbb{D}}$, Paweł Nowak ${ }^{1}{ }^{1}$, Joanna Empel ${ }^{2}$, Magdalena Tomczak ${ }^{2}$, Joanna Klepacka ${ }^{3}$, \\ Iwona Sowa-Sierant $^{3}$, Iwona Żak ${ }^{3}$ (D), Bartosz Pomierny ${ }^{4}$ (D) and Elżbieta Karczewska ${ }^{1, *(D)}$
}

1 Department of Pharmaceutical Microbiology, Faculty of Pharmacy, Jagiellonian University Medical College, Medyczna 9 Street, 30-688 Krakow, Poland; iwona.skiba@uj.edu.pl (I.S.-K.); p.nowak@uj.edu.pl (P.N.)

2 Department of Epidemiology and Clinical Microbiology, National Medicines Institute, Chełmska 30/34 Street, 00-725 Warsaw, Poland; j.empel@nil.gov.pl (J.E.); m.tomczak@nil.gov.pl (M.T.)

3 Department of Clinical Microbiology, University Children's Hospital of Krakow, Wielicka 256 Street, 30-663 Krakow, Poland; jklepacka@usdk.pl (J.K.); isowa@usdk.pl (I.S.-S.); izak@usdk.pl (I.Ż.)

4 Department of Toxicology, Faculty of Pharmacy, Jagiellonian University Medical College, Medyczna 9 Street, 30-688 Kraków, Poland; bartosz.pomierny@uj.edu.pl

* Correspondence: elzbieta.karczewska@uj.edu.pl; Tel.: +481-2620-5750; Fax: +481-2620-5758

Citation: Skiba-Kurek, I.; Nowak, P.; Empel, J.; Tomczak, M.; Klepacka, J.; Sowa-Sierant, I.; Żak, I.; Pomierny, B.; Karczewska, E. Evaluation of Biofilm Formation and Prevalence of Multidrug-Resistant Strains of Staphylococcus epidermidis Isolated from Neonates with Sepsis in Southern Poland. Pathogens 2021, 10, 877. https://doi.org/10.3390/ pathogens 10070877

Academic Editor: Bryan Heit

Received: 14 May 2021

Accepted: 8 July 2021

Published: 11 July 2021

Publisher's Note: MDPI stays neutral with regard to jurisdictional claims in published maps and institutional affiliations.

Copyright: (c) 2021 by the authors. Licensee MDPI, Basel, Switzerland. This article is an open access article distributed under the terms and conditions of the Creative Commons Attribution (CC BY) license (https:/ / creativecommons.org/licenses/by/ $4.0 /)$.
Abstract: Staphylococcus epidermidis strains play an important role in nosocomial infections, especially in the ones associated with biofilm formation on medical devices. The paper was aimed at analyzing the mechanisms of antibiotic resistance and confirming the biofilm-forming ability among S. epidermidis strains isolated from the blood of hospitalized newborns. Genetic analysis of resistance mechanism determinants included multiplex PCR detection of $m e c A, \operatorname{erm} A, \operatorname{ermB}, \operatorname{erm} C, m s r A$, and mef genes. Biofilm analysis comprised phenotypic and genotypic methods including Christensen and Freeman methods and PCR detection of the icaADB gene complex. Among the tested S. epidermidis strains, $89 \%$ of the isolates were resistant to methicillin, $67 \%$ - to erythromycin, $53 \%$-to clindamycin, $63 \%$-to gentamicin, and $23 \%$ - to teicoplanin, while all the strains were susceptible to vancomycin and linezolid. The mecA gene was detected in $89 \%$ of the isolates, the erm $C$ gene was the most common and present among $56 \%$ of the strains, while the $m s r A$ gene was observed in $11 \%$ isolates. Eighty-five percent of the strains were described as biofilm-positive by phenotypic methods and carried the ica $A D B$ gene cluster. Multidrug resistance and the biofilm-forming ability in most of the strains tested may contribute to antimicrobial therapy failure $(p<0.05)$.

Keywords: Staphylococcus epidermidis; antibiotic resistance; MRSE; biofilm; ica genes; neonatal septicemia; nosocomial infections

\section{Introduction}

Hospital-acquired infections are among the major challenges in current epidemiology and public health [1]. Gram-positive cocci, especially Staphylococcus aureus and Staphylococcus epidermidis resistant to methicillin (methicillin-resistant S. aureus (MRSA); methicillin-resistant $S$. epidermidis (MRSE)), have been increasingly prevalent etiological factors of nosocomial infections worldwide [2].

Since $S$. epidermidis colonizes human skin and mucosa during the first few hours of life, after $24 \mathrm{~h}$, skin of most healthy neonates ( $84 \%)$ is colonized by this bacterial species [3]. Furthermore, S. epidermidis can cause opportunistic infections in mature and premature neonates. Infants with low birth weight, immature immune system, and/or damaged skin and mucous membranes are particularly vulnerable. Serious clinical conditions requiring catheterization (venous, urinary, or umbilical), mechanical ventilation, tracheal intubation, parenteral nutrition, or other medical procedures may enhance the risk of infection and sepsis [4,5]. A variety of equipment used in the modern therapy of newborns such as 
respirators, infusion pumps, monitoring devices, thermometers, stethoscopes, or suction devices may contribute to the spread of the bacteria [6,7].

Premature or sick newborns are mainly treated at neonatal intensive care units (NICU). Hospitalization for more than twenty days is a risk factor for neonatal sepsis, osteomyelitis, dermatitis, necrotizing enterocolitis, and surgical wound infections [8]. The main etiological agents of these infections are coagulase-negative staphylococci, which are frequently multidrug-resistant. Virulence factors of these bacteria enable them to escape the host's immune response and facilitate adhesion to host tissues and foreign materials [9]. One of the most important S. epidermidis virulence factors is extracellular secretion of mucus which facilitates bacterial adhesion to biomaterials, i.e., to the plastic materials used to manufacture medical devices, such as prostheses and catheters [10]. Microorganisms attached to solid surfaces and surrounded by self-produced extracellular polymeric substances (EPS) constitute structurally and functionally complex communities known as the biofilm. As the biofilm develops, bacterial cells aggregate to form microcolonies immersed in the extracellular matrix (ECM) incised with a network of canals containing exopolysaccharides and other organic compounds, e.g., proteins, teichoic acids, nucleic acids, and phospholipids [11]. The resistance of biofilms to toxic substances is likely to be caused by their complex structure, especially by the exopolysaccharide content of the extracellular matrix. EPS form a gel-like substance that acts as a physical barrier against the penetration of antimicrobial agents into bacterial cells [12]. Biofilms prevent penetration of phagocytes, antibodies, and antibiotics into bacterial cells thus increasing their resistance to drugs and disinfectants. Furthermore, metabolism of biofilm-forming bacteria is slowed down and they undergo phenotypic changes determining their resistance and virulence. Moreover, mechanical disruption of the biofilm structure can lead to the dispersal of aggregated bacteria into the bloodstream thus causing dissemination of infection [13].

Methicillin-resistant S. epidermidis (MRSE) strains pose an essential threat to hospitalized patients. This mechanism of resistance is associated with the acquisition of the mec $A$ gene encoding a specific penicillin-binding protein (PBP2a) and characterized by substantially lower affinity to $\beta$-lactam antibiotics [14]. Besides $\beta$-lactam resistance, clinical MRSE strains may also acquire resistance to other groups of antimicrobial agents (including aminoglycosides, macrolides, fluoroquinolones, or tetracyclines) used in the therapy of staphylococcal infections. Another clinically important mechanism present among $S$. epidermidis strains includes resistance to macrolides, lincosamides, and streptogramins $B$ $\left(\mathrm{MLS}_{\mathrm{B}}\right)$ [15]. This mechanism is associated with target site modification, efflux pumps, and enzymatic modification of antibiotics. The most prevalent mechanism is related to target site modifications of ribosomes by methylases encoded by erm genes and results in the resistance to all $\mathrm{MLS}_{\mathrm{B}}$ antibiotics. Furthermore, the resistance only to 14 and 15-membered macrolides and streptogramins B is associated with msr-encoded efflux pumps [16]. The third mechanism is related to enzymatic inactivation of lincosamides [17].

While Staphylococcus epidermidis may be the causative agent of severe hospital-acquired infections in some clinical cases, it is difficult to distinguish between the infection and contamination of the clinical specimen. It has been noted that the strains causing infections are more likely to carry genetic determinants of resistance, pathogenicity, and biofilm, but the results obtained so far suggest that there is no single distinction marker which can be used in routine diagnostics. Therefore, the studies concerning the analysis of Staphylococcus epidermidis virulence, resistance, and biofilm formation contribute to enhancing the knowledge concerning this important bacterium [18,19].

The aims of the study included the analysis of (1) antimicrobial susceptibility, (2) selected resistance phenotypes and genotypes, (3) biofilm formation (among the group of clinical S. epidermidis strains isolated at the University Children's Hospital in Krakow), and (4) the evaluation of the biofilm detection method. Therefore, the study of the phenotype and the genotypic characterization of virulence of clinical S. epidermidis isolates is of great value in understanding their roles in the pathogenesis. 


\section{Results}

\subsection{Species Identification of the Tested Strains}

The species S. epidermidis was confirmed in phenotypic (classical microbiology identification methods and the biochemical API Staph test (bioMérieux, Poland, Figure 1)) and genetic studies (the presence of a 124-bp amplicon-specific fragment for S. epidermidis species, Figure 2) of all the tested strains [20]. The identification of S. epidermidis was confirmed, while 89/100 samples were mecA(+) (Supplementary Material Table S1).

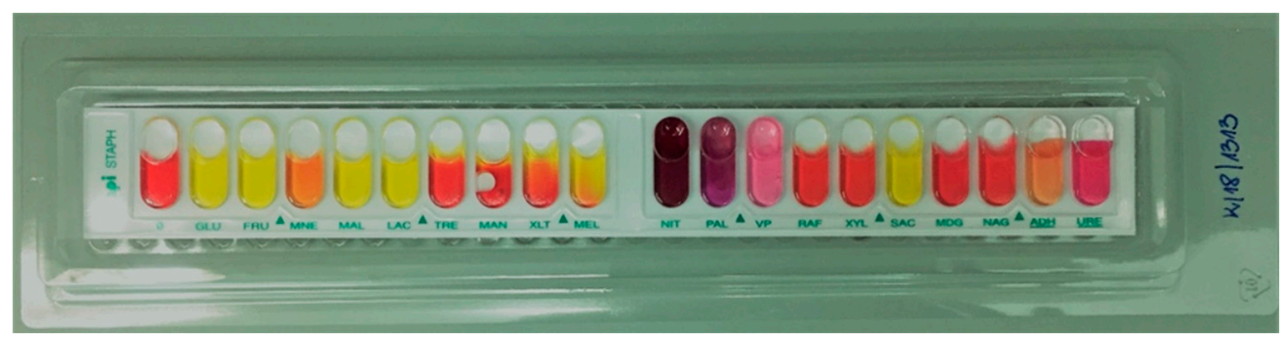

Figure 1. Identification strip of the API Staph system (bioMérieux, Poland). The metabolic processes taking place during incubation change the color of the substrates. The photo shows the identification strip for the clinical strain S. epidermidis $\mathrm{K} / 18 / 1313$.

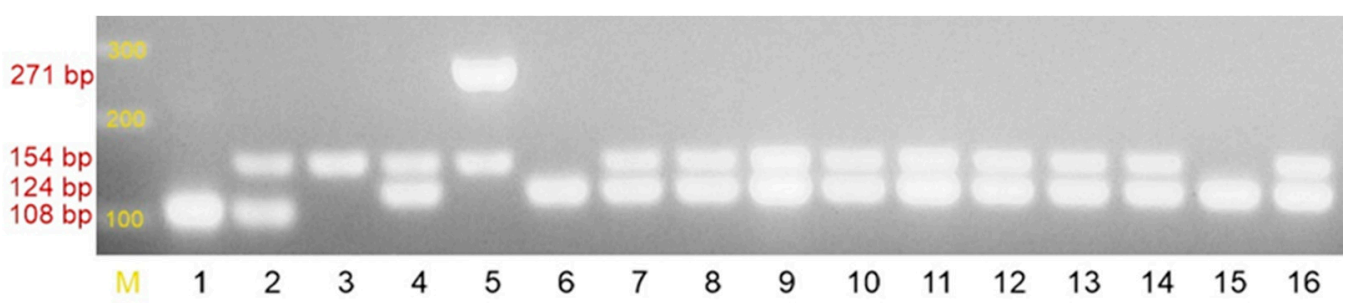

Figure 2. Agarose gel electrophoresis of multiplex PCR performed in order to identify bacterial species and detect the presence of the mecA gene: M-DNA molecular weight marker 100 bp (GeneRuler 100 bp DNA Ladder, ThermoFisher Scientific), 1-. aureus ATCC 25923 mecA(-) strain, 2-S. aureus ATCC 43300 mecA(+) strain, 3-clinical mecA(+) strain, 4- clinical Staphylococcus epidermidis strain, 5-Staphylococcus haemolyticus ATCC 29970 strain, 6-Staphylococcus epidermidis ATCC 12228 strain, 7-16-clinical Staphylococcus epidermidis strains. List of expected amplicons for (1) species identification: S. aureus-108 bp; S. epidermidis-124 bp; S. haemolyticus-271 bp; (2) mecA gene-154 bp.

\subsection{Resistance to Methicillin}

The resistance to methicillin was tested in parallel using the disk diffusion ( $30 \mu \mathrm{g}$ cefoxitin) and multiplex PCR techniques (the presence of a mecA amplicon of $154 \mathrm{bp}$ ) [20]. Of the 100 tested strains, $89 \%$ confirmed both methicillin resistance (MRSE) by the disk diffusion method and presence of the mecA gene (Figure 2, Supplementary Material Table S1).

\subsection{Macrolide, Lincosamide, and Streptogramin (MLS) Resistance Mechanisms}

The phenotypic method showed that $53(53 \%)$ isolates had the constitutive resistance phenotype $\left(\mathrm{cMLS}_{\mathrm{B}}\right)$, and three $(3 \%)$ had the inducible resistance phenotype (iMLS $\mathrm{B}_{\mathrm{B}}$ ). The strains demonstrating either constitutive or inducible mechanism of resistance to macrolides, lincosamides, and streptogramins B should be reported as resistant to clindamycin. The $\mathrm{MS}_{\mathrm{B}}$ phenotype was identified in $11(11 \%)$ strains so neither macrolides (comprising a 14- or 15-membered ring) nor streptogramins B should be used as therapeutic agents.

Two separate PCR assays were used to detect erythromycin resistance genes: the first one detected the erm $A$, erm $C$, and $m s r A$ genes while the second assay identified the ermB and mef genes [21]. The erm C gene (amplicon size of $190 \mathrm{bp}$ ) was detected in $56(56 \%)$ strains in which the presence of the $\mathrm{MLS}_{\mathrm{B}}$ (either constitutive and inducible) resistance mechanism was detected by phenotypic testing, whereas the $11(11 \%)$ strains previously 
identified as $\mathrm{MS}_{\mathrm{B}}$ carried the $m s r A$ gene (product size of $163 \mathrm{bp}$ ) encoding an efflux pump, a member of the ATP-dependent membrane superfamily of transporters (ABC transporters) (Figure 3, Supplementary Materials).

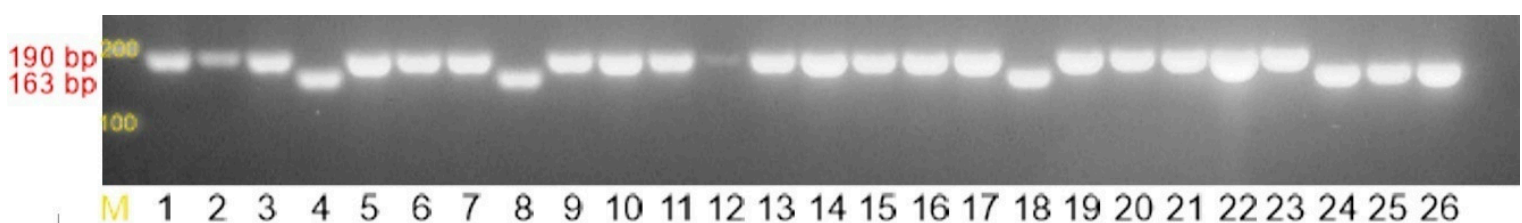

Figure 3. Agarose gel electrophoresis of multiplex PCR products determining the resistance to macrolides, lincosamides, and streptogramins B: ermC (190 bp), msrA (163 bp). M-DNA molecular weight marker 100 bp (GeneRuler 100 bp DNA Ladder, ThermoFisher Scientific), 1-25-linical strains of Staphylococcus epidermidis, 26-Staphylococcus aureus ATCC BAA-976 $m s r A(+)$ strain.

According to the disk diffusion test, $63(63 \%)$ strains were resistant to gentamicin. All isolates were susceptible to linezolid $(n=100)$. Furthermore, it was confirmed that all the tested S. epidermidis strains were susceptible to vancomycin with the MIC values ranging from 0.25 to $3 \mu \mathrm{g} / \mathrm{mL}$. Resistance to teicoplanin was found in $23(23 \%)$ of the S. epidermidis isolates with the MIC values ranging from 6 to $16 \mu \mathrm{g} / \mathrm{mL}$ (Figure 4, Supplementary Material Table S1). No intermediate susceptible strains were found.

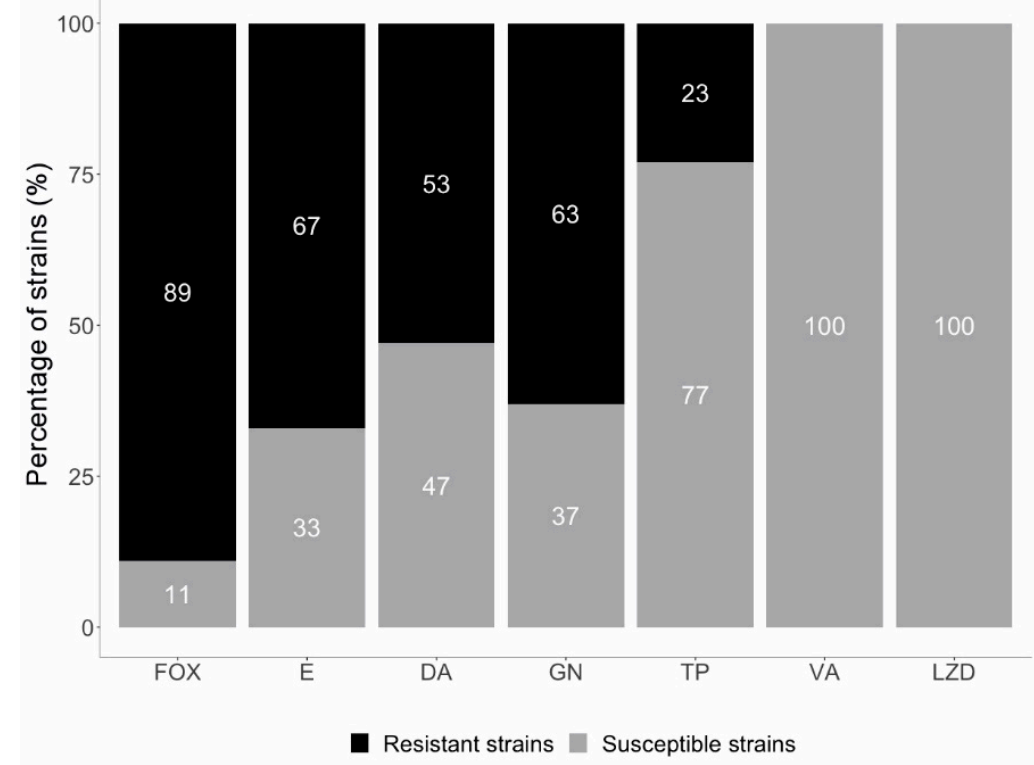

Figure 4. Susceptibility of the tested S. epidermidis strains (FOX — cefoxitin, E-erythromycin, DAclindamycin, GN—gentamicin, TP—-teicoplanin, VA—vancomycin, LZD—linezolid).

\subsection{Biofilm-Forming Capacity}

According to the results obtained using the method described by Freeman [22], 86\% $(n=86)$ of the S. epidermidis strains formed a biofilm. The biofilm-positive strains produced black, usually matte colonies when grown on the Congo Red supplemented medium. The remaining $14 \%(n=14)$ of the strains were unable to form a biofilm; they formed intense red colonies (Figure 5, Supplementary Material Table S1). 


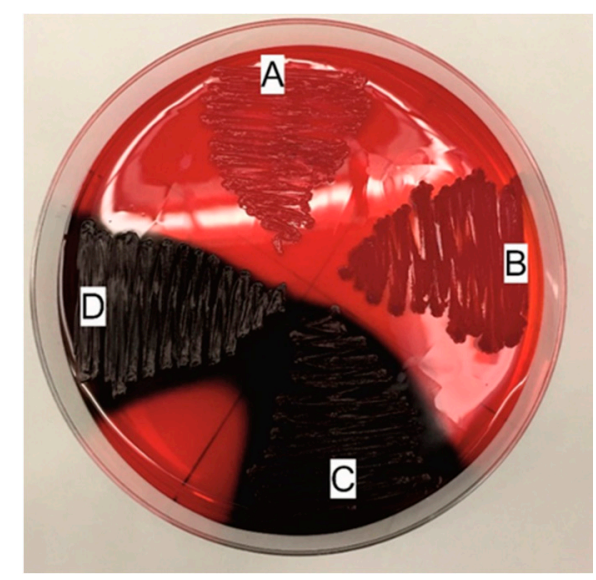

Figure 5. Freeman method-qualitative evaluation of the biofilm-forming capacity of the bacteria cultured on a Congo Red-containing medium. A-non-biofilm producer Staphylococcus epidermidis ATCC 12228 (the negative control), B-non-biofilm producer K/18/313 (clinical strain), C—biofilm producer S. epidermidis ATCC 35984 (the positive control), D-biofilm producer K/12/8915 (clinical strain).

The strains which produced a biofilm outnumbered the strains which were unable to form a biofilm $\left(\chi^{2}=49.00, p<0.001\right)$.

Furthermore, when Christensen (quantitative) method [23] was applied, the results showed that $86 \%(n=86)$ of the tested strains were strong biofilm producers. Moderate and weak biofilm producers comprised 3\% $(n=3)$ and 11\% $(n=11)$, respectively. The strains were classified (Table 1, Supplementary Material Table S1). It is worth noting that in three $(3 \%)$ of the tested strains, Christensen method confirmed the production of a biofilm with medium intensity, while when Freeman method was used, the strains grew red, and the presence of the icaADB gene cluster was not confirmed. Staining with crystal violet showed that the studied strains rapidly formed biofilms in vitro (Table 1).

Table 1. Biofilm production by Staphylococcus epidermidis isolates according to Christensen method.

\begin{tabular}{ccc}
\hline Average OD Value & $\boldsymbol{N}(\boldsymbol{\%})$ & Biofilm Formation \\
\hline OD $\leq 0.09$ & $0(0 \%)$ & No \\
$0.09<\mathrm{OD} \leq 0.18$ & $11(11 \%)$ & Weak \\
$0.18<\mathrm{OD} \leq 0.36$ & $3(3 \%)$ & Moderate \\
$0.36<\mathrm{OD}$ & $86(86 \%)$ & Strong \\
\hline
\end{tabular}

* Optical density cutoff value (ODc) $=$ average OD of the negative control $+3 \times$ standard deviation (SD) of the negative control (Staphylococcus epidermidis ATCC 12228 ODc $=0.06+3 \times 0.01=0.09$ ); N-overall frequency; $\%$-percentage.

The strains characterized by resistance mechanisms such as $\mathrm{MLS}_{\mathrm{B}}, \mathrm{MS}_{\mathrm{B}}$, as well as resistance to methicillin, gentamicin, and teicoplanin had a strong ability to produce a biofilm (as shown in Tables 2 and 3).

The group of strains with methicillin resistance mechanisms outnumbered the group without such a mechanism, $\chi^{2}=60.84, p<0.001$. The strains with another type of mechanism $\left(\mathrm{MLS}_{\mathrm{B}}, \mathrm{MS}_{\mathrm{B}}\right)$ outnumbered the strains without such a mechanism, $\chi^{2}=26.48$, $p<0.001$.

Additionally, when we compared the numbers of strains with both types of the resistance mechanism, we statistically proved that groups with MRSE $+\mathrm{MLS}_{\mathrm{B}}$ or $\mathrm{MS}_{\mathrm{B}}$ were the largest, $\chi^{2}=122.6, p<0.001$.

We obtained more strains resistant to gentamicin $\left(\chi^{2}=6.76, p<0.01\right)$ and teicoplanin $\left(\chi^{2}=29.16, p<0.001\right)$ than without the ability to resist to both antibiotics. 
Table 2. Comparison of resistance to methicillin, macrolides, lincosamides, and streptogramins with biofilm determination using different methods within the analyzed group of Staphylococcus epidermidis strains obtained from pediatric patients.

\begin{tabular}{|c|c|c|c|c|c|c|c|}
\hline \multirow{3}{*}{$\begin{array}{l}\text { Resistance } \\
\text { Mechanisms }\end{array}$} & \multicolumn{7}{|c|}{ Biofilm Formation } \\
\hline & \multicolumn{3}{|c|}{$\begin{array}{c}\text { Christensen Method } \\
\text { N (\%) }\end{array}$} & \multicolumn{2}{|c|}{$\begin{array}{c}\text { Freeman Method } \\
N(\%)\end{array}$} & \multicolumn{2}{|c|}{$\begin{array}{c}\text { icaADB Gene Cluster } \\
N(\%)\end{array}$} \\
\hline & Strong & Moderate & Weak & Black & Red & Presence & Absence \\
\hline MRSE & $22(79 \%)$ & $1(3 \%)$ & $5(18 \%)$ & $22(79 \%)$ & $6(21 \%)$ & $22(79 \%)$ & $6(21 \%)$ \\
\hline$M R S E+M_{B}$ & $48(91 \%)$ & $2(4 \%)$ & $3(5 \%)$ & $48(91 \%)$ & $5(9 \%)$ & $48(91 \%)$ & $5(9 \%)$ \\
\hline $\mathrm{MRSE}+\mathrm{MS}_{\mathrm{B}}$ & $7(88 \%)$ & 0 & $1(12 \%)$ & $6(75 \%)$ & $2(25 \%)$ & $6(75 \%)$ & $2(25 \%)$ \\
\hline $\mathrm{MLS}_{\mathrm{B}}$ & $1(100 \%)$ & 0 & 0 & $1(100 \%)$ & 0 & $1(100 \%)$ & 0 \\
\hline $\mathrm{MS}_{\mathrm{B}}$ & $4(100 \%)$ & 0 & 0 & $4(100 \%)$ & 0 & $4(100 \%)$ & 0 \\
\hline None & $4(67 \%)$ & 0 & $2(33 \%)$ & $4(67 \%)$ & $2(33 \%)$ & $4(67 \%)$ & $2(33 \%)$ \\
\hline Total & $86(86 \%)$ & $3(3 \%)$ & $11(11 \%)$ & $85(85 \%)$ & $15(15 \%)$ & $85(85 \%)$ & $15(15 \%)$ \\
\hline
\end{tabular}

MRSE-methicillin-resistant Staphylococcus epidermidis; $\mathrm{MLS}_{\mathrm{B}}$-macrolides, lincosamides, and streptogramins B; $\mathrm{MS}_{\mathrm{B}}$-macrolides and streptogramins B; N-overall frequency; \%-percentage.

Table 3. Comparison of resistance to gentamycin and teicoplanin of Staphylococcus epidermidis strains obtained from pediatric patients with biofilm determination using different methods.

\begin{tabular}{|c|c|c|c|c|c|c|c|}
\hline \multicolumn{8}{|c|}{ Biofilm Formation } \\
\hline \multirow{2}{*}{ Antibiotics } & \multicolumn{3}{|c|}{$\begin{array}{c}\text { Christensen Method } \\
\text { N (\%) }\end{array}$} & \multicolumn{2}{|c|}{$\begin{array}{c}\text { Freeman Method } \\
\qquad N(\%)\end{array}$} & \multicolumn{2}{|c|}{$\begin{array}{c}\text { icaADB Gene Cluster } \\
N(\%)\end{array}$} \\
\hline & Strong & Moderate & Weak & Black & Red & Presence & Lack \\
\hline \multicolumn{8}{|l|}{ Gentamicin } \\
\hline$R^{*}$ & $57(91 \%)$ & $2(3 \%)$ & $4(6 \%)$ & $56(89 \%)$ & $7(11 \%)$ & $56(89 \%)$ & $7(11 \%)$ \\
\hline$S^{* *}$ & $29(78 \%)$ & $1(3 \%)$ & $7(7 \%)$ & $29(78 \%)$ & $8(22 \%)$ & $29(78 \%)$ & $8(22 \%)$ \\
\hline \multicolumn{8}{|l|}{ Teicoplanin } \\
\hline R & $20(87 \%)$ & $1(9 \%)$ & $2(4 \%)$ & $19(83 \%)$ & $4(17 \%)$ & $19(83 \%)$ & $4(17 \%)$ \\
\hline$S$ & $66(86 \%)$ & $2(3 \%)$ & $9(12 \%)$ & $66(86 \%)$ & $11(14 \%)$ & $66(86 \%)$ & $11(14 \%)$ \\
\hline
\end{tabular}

\subsection{Application of Logistic Regression to Predict A Dichotomous Variable for Three Biofilm Incidence Study Models}

We also tested if we could predict biofilm formation (dependent variable) based on a few independent variables (types of resistance mechanisms, resistance to gentamicin and teicoplanin). To check these assumptions, we ran the logistic regression on the presented data (86 observations). We did not have to exclude any outliers, and the variables did not show any collinearity. The statistical analysis concerning the simultaneous impact of the independent variables on biofilm formation demonstrates that none of the above regressors was statistically significant. Consequently, types of resistance mechanisms, resistance to gentamicin and teicoplanin, cannot help in predicting the appearance of a biofilm.

The statistical analysis concerning the simultaneous impact of resistance mechanisms, resistance to gentamycin and teicoplanin, as well as the presence of a biofilm confirmed by three methods showed that none of the regressors above was statistically significant.

For Freeman method of biofilm formation, the chi-squared test indicated that the tested model was statistically insignificant, $\chi^{2}=4.61, p=0.466$ (Table 4).

For Christensen method of biofilm formation, the chi-squared test indicated that the tested model was not statistically significant, $\chi^{2}=2.81, p=0.73$. For the results, see Table 5 .

For the genetic method of biofilm formation, the chi-squared test indicated that the tested model was statistically insignificant, $\chi^{2}=4.61, p=0.466$. For the results, see Table 6 . 
Table 4. Results of logistic regression for the biofilm formation by S. epidermidis (Freeman method).

\begin{tabular}{ccccc}
\hline & $B$ & $p$-Value & Exp(B) & 95\% CI \\
\hline Resistance mechanism 0 & & 0.369 & & 0.61 \\
Resistance mechanism MLS & -0.50 & 0.573 & 1.53 & $0.11-3.47$ \\
Resistance mechanism MS & 0.43 & 0.665 & 0.80 & $0.22-10.65$ \\
Resistance mechanism MRSE & -0.22 & 0.811 & 0.51 & $0.13-4.90$ \\
Resistance to gentamycin & -0.68 & 0.305 & 1.63 & $0.14-1.86$ \\
Resistance to teicoplanin & 0.49 & 0.486 & 6.49 & $0.41-6.47$ \\
Constant & 1.87 & 0.148 & & \\
\hline
\end{tabular}

Table 5. Results of logistic regression for the biofilm formation by S. epidermidis (Christensen method).

\begin{tabular}{ccccc}
\hline & $\boldsymbol{B}$ & $\boldsymbol{p}$-Value & Exp(B) & 95\% CI \\
\hline Resistance mechanism 0 & & 0.284 & & \\
Resistance mechanism MLS & -1.39 & 0.224 & 4.01 & $0.43-37.52$ \\
Resistance mechanism MS & -0.57 & 0.641 & 1.78 & $0.16-19.77$ \\
Resistance mechanism MRSE & -0.09 & 0.921 & 1.09 & $0.17-6.97$ \\
Resistance to gentamycin & -0.91 & 0.177 & 2.48 & $0.67-9.24$ \\
Resistance to teicoplanin & 0.16 & 0.831 & 0.85 & $0.19-3.78$ \\
Constant & 3.05 & 0.044 & 0.05 & \\
\hline
\end{tabular}

Table 6. Results of logistic regression for the icaADB gene cluster.

\begin{tabular}{ccccc}
\hline & $\boldsymbol{B}$ & $\boldsymbol{p}$-Value & $\mathbf{E x p ( B )}$ & $\mathbf{9 5 \%} \mathbf{C I}$ \\
\hline Resistance mechanism 0 & & 0.369 & & \\
Resistance mechanism MLS & -0.50 & 0.573 & 0.61 & $0.11-3.47$ \\
Resistance mechanism MS & 0.43 & 0.665 & 1.53 & $0.22-10.65$ \\
Resistance mechanism MRSE & -0.22 & 0.811 & 0.80 & $0.13-4.90$ \\
Resistance to gentamycin & -0.68 & 0.305 & 0.51 & $0.14-1.86$ \\
Resistance to teicoplanin & 0.49 & 0.486 & 1.63 & $0.41-6.47$ \\
Constant & 1.87 & 0.148 & 6.49 & \\
\hline
\end{tabular}

Please note that the results for logistic regressions for Freeman method and the genetic method were the same. Both methods gave exactly the same results for biofilm marking. Freeman method, although easier and faster to perform than the icaADB gene cluster detection, can be recommended as a screening test for identifying biofilm production by S. epidermidis strains.

PCR analyses showed that 86 out of the 100 strains carried the icaADB gene cluster [24] which gave a product of 546 bp (Figure 6, Supplementary Material Table S1).

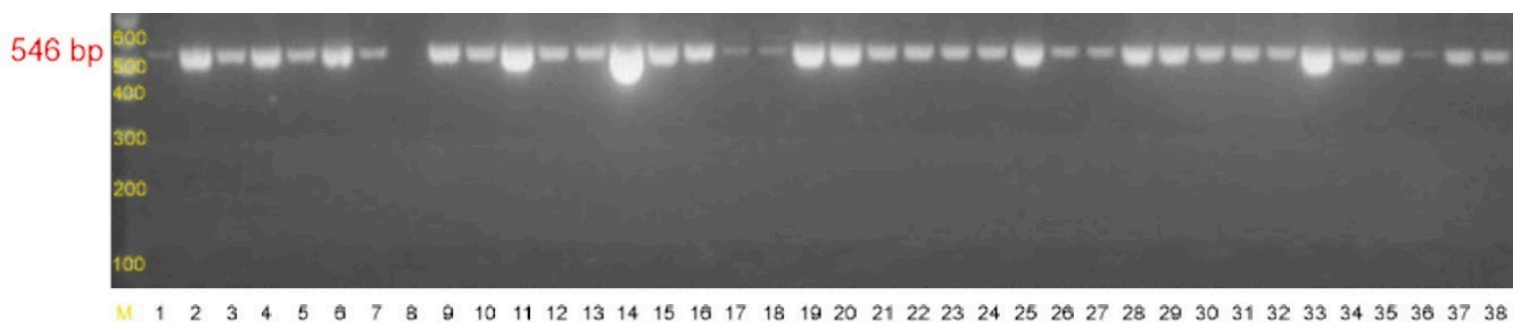

Figure 6. Agarose gel electrophoresis of PCR products of the icaADB gene with the size of $546 \mathrm{bp}$. M-DNA molecular weight marker 1000 bp (DNA Marker 1, A\&A Biotechnology Poland), 1-S. epidermidis ATCC 35984 icaADB(+) strain, 2-28-clinical strains of Staphylococcus epidermidis. 


\section{Discussion}

Staphylococcus epidermidis is the third most significant pathogen associated with hospital-acquired infections. In Poland, this bacterium is the main pathogen responsible for bloodstream infections in neonatal units $[25,26]$. Resistance of $S$. epidermidis strains to methicillin is a significant clinical problem associated with the expression of the $m e c A$ gene encoding altered penicillin-binding protein PBP2a ( $\mathrm{PBP}^{\prime}$ ) [14,27]. Brzychczy-Włoch et al. [28], who analyzed 63 S. epidermidis strains, obtained similar results: $98 \%$ of the strains were methicillin-resistant. The research of Al-Mulla et al. [29] revealed the presence of 26 S. epidermidis clinical strains isolated from children staying at hospital departments of hematology and oncology, and they also demonstrated a high percentage of methicillin-resistant isolates (77\%). In another study by Najar-Peerayeh et al. [30], 92.2\% of the investigated strains isolated from intensive care patients were resistant to methicillin. Chaieb et al. [21] examined 33 clinical S. epidermidis strains and revealed that $78.1 \%$ of the isolates carried the mecA gene. Notably, the rate of MRSE strains ( $89 \%$ ) found in our study was within the range reported globally (75-90\%) [31].

Resistance to erythromycin was observed in $67 \%$ of the tested strains. Similar results were obtained by Szczuka et al. [32] who classified $76 \%$ of the studied strains as erythromycinresistant. On the other hand, Wojtyczka et al. [33] reported a two times smaller number of erythromycin-resistant strains (43.7\%), whereas Brzychczy-Włoch et al. [28] found 84\% of the tested strains to be erythromycin-resistant. Of the 100 analyzed isolates, $40 \%$ had the constitutive resistance phenotype ( $\left.\mathrm{cMLS}_{\mathrm{B}}\right), 27 \%$ had the inducible resistance phenotype $\left(\mathrm{iMLS}_{\mathrm{B}}\right)$, and $11 \%$ were identified to have the $\mathrm{MS}_{\mathrm{B}}$ resistance phenotype. Similar results were reported by Szczuka et al. [32] who observed that more than half of the analyzed isolates expressed the MLS ${ }_{B}$ phenotype of resistance, and most of them-the constitutive phenotype, whereas in the study by Brzychczy-Włoch et al. [28], the constitutive phenotype of resistance $\left(\mathrm{cMLS}_{\mathrm{B}}\right)$ was found in $43 \%$ of the strains, inducible phenotype (iMLS $\mathrm{B}_{\mathrm{B}}$ ) -in $16 \%$, and $\mathrm{MS}_{\mathrm{B}}$ - in $40 \%$ of the analyzed isolates. Juda et al. [34] reported the constitutive phenotype of resistance $\left(\mathrm{cMLS}_{\mathrm{B}}\right)$ in $36 \%$, inducible phenotype $\left(\mathrm{iMLS}_{\mathrm{B}}\right)$-in $18.7 \%$, and $\mathrm{MS}_{\mathrm{B}}$-in $45.3 \%$ of the studied strains.

The occurrence of genes responsible for erythromycin resistance was confirmed by two independent multiplex PCR reactions (respectively, erm $A$, erm C, msr A, ermB, and mef genes). The erm $C$ gene appeared to be the most prevalent among the analyzed S. epidermidis isolates. Similar results were obtained by Chaieb et al. [21], Brzychczy-Włoch et al. [28], and Juda et al. [34] who reported the predominance of the erm C and msr $A$ genes and did not observe any formation of the mef gene product. In the publication by Szemraj et al. [35], the MLS $_{\mathrm{B}}$ resistance mechanism was common in S. hominis, S. haemolyticus, and S. epidermidis isolates-respectively, in $100 \%, 78 \%$, and $59 \%$ of the isolates. In most cases, it was the constitutive type. The type of the erm gene also depends on the geographical region of isolation. For example, erm C was previously detected in $50 \%$ of the strains exhibiting the $\mathrm{MLS}_{\mathrm{B}}$ resistance in Great Britain, whereas it was detected in $90 \%$ of those originating from Denmark. The distribution of erm genes depends on the bacterial species [36].

Sixty-three percent $(n=63)$ of the strains proved to be gentamicin-resistant. Al-Mulla et al. [29] found that $23 \%$ of the analyzed strains were resistant to gentamicin, whereas Szczuka et al. [32] reported a higher percentage of resistance (47\%). Other authors obtained even higher results, such as Brzychczy-Włoch et al. (93\%) [28] and Białkowska-Hobrzańska et al. (85\%) [37]. New breakpoints for aminoglycosides were published in the 2021 EUCAST clinical breakpoint tables (v 11.0). In systemic infections, aminoglycosides must be used in combination therapy. In such situations, the breakpoints in parentheses can be used to distinguish organisms with acquired resistance mechanisms from wild-type strains without resistance mechanisms [38].

Vancomycin is mainly used to treat severe or complicated infections caused by multiresistant bacteria including Staphylococcus spp., Enterococcus spp., and Streptococcus spp. (Streptococcus pneumoniae). In clinical practice, vancomycin is effective in the therapy of skin and soft tissue infection, pneumonia, urinary infection, endocarditis, prosthetic device- 
associated infection, blood stream infections, and other systemic infections. Resistance to teicoplanin accompanied by susceptibility to vancomycin might be explained by incomplete cross-resistance which is a common feature of the abovementioned group of antibiotics. It should be noted that teicoplanin exhibits a lower bactericidal activity against S. epidermidis [39]. All the tested isolates were susceptible to vancomycin (MIC $<4 \mu \mathrm{g} / \mathrm{mL}$ ), but $23 \%$ of these strains were resistant to teicoplanin (MIC $>4 \mu \mathrm{g} / \mathrm{mL}$ ). Tevell et al. [40] and Najar-Peerayeh et al. [30] also reported 100\% susceptibility to vancomycin, but only $11.5 \%$ strains were teicoplanin-resistant in their studies. The results obtained by Brzychczy-Włoch et al. [28] and Tevell et al. [40] were similar (100\% susceptibility to vancomycin and 13\% resistance to teicoplanin). The results reported by Al-Mulla et al. [29] were much the same (23\% of the strains resistant to teicoplanin in the absence of vancomycin-resistant isolates).

Researchers do not agree about the effect of biofilm-forming capacity on the pathogenicity of staphylococcal strains. Some of them consider biofilm to play only a negligible role in the pathogenesis of infection, while others believe that the biofilm-forming capacity distinguishes between the commensal and pathogenic bacteria $[41,42]$.

According to the results obtained by the method of Freeman, $86 \%$ of the analyzed $S$. epidermidis strains produced a biofilm and released it extracellularly in contrast to $14 \%$ of the strains not producing a biofilm. There is only scarce data on strains isolated from patients of neonatal departments. According to the studies of Grzebyk et al. [43], as much as 90\% of the S. epidermidis strains produced a biofilm, which was demonstrated using Freeman method. Other authors reported that, on average, $71-73 \%$ of the $S$. epidermidis strains exhibited mucoid colony morphologies when grown on the Congo Red agar [44,45]. A study of biofilm production by Christensen method indicated that $90 \%$ of the S. epidermidis strains produced a biofilm, of which $87 \%$ were strong biofilm producers and $3 \%$ were moderate biofilm producers. Similar results were obtained by the teams of Indian [46] and Latvian researchers [47].

Of the 100 analyzed isolates, 86 carried the icaADB genes encoding the polysaccharide intercellular adhesin. Similar results were obtained by Lìduma et al. [47], whereas Cafiso et al. [45] and Oliveira et al. [44] reported that only $45 \%$ of the analyzed strains carried the icaADB gene cluster. Consistent results were obtained using the abovementioned methods.

In our research, $3 \%$ of the strains described as moderate biofilm producers by Christensen (quantitative) method did not carry the ica gene and gave a negative result on the Congo Red agar. Biofilm-forming S. epidermidis strains in which the genes for the ica operon were not found have been described by Fraiha et al. [48,49]. It is considered that the role is taken over by accumulation-associated protein aap and autolysin at $l \mathrm{E}$ [50,51].

Since recently, a new concept of biofilm-related disease has emerged in medical science [52]. Biofilm-related diseases result from infections associated with the use of medical implants, chronic infections in which biomaterials are not involved, and even malfunction of life-supporting equipment [53]. An example of a significant biofilm role in the course of a disease could be pneumonia in patients with cystic fibrosis. While most studies have been focused on Pseudomonas aeruginosa infections, relatively fewer articles have attempted to understand the role of a Staphylococcus aureus biofilm in cystic fibrosis. Pietruczuk-Padzik et al. [54] demonstrated that Staphylococcus aureus strains isolated from the respiratory tract of cystic fibrosis patients are capable of forming a biofilm in vitro and may cause chronic respiratory infections. The aim of the study was to evaluate two screening methods for detecting biofilm formation by eighty clinical Staphylococcus aureus isolates from cystic fibrosis patients and to evaluate biofilm production in 96-well polystyrene tissue culture plates depending on the culture medium used (Luria-Bertani broth (LB), tryptic soy broth supplemented with $2 \%$ glucose (TSBglu), and brain heart infusion (BHI)). 


\section{Materials and Methods}

\subsection{Phenotypic Methods}

\subsubsection{Bacterial Strains}

One hundred S. epidermidis nonduplicate isolates from the blood $(n=96)$, cerebrospinal fluid $(n=3)$, and dialysis fluid $(n=1)$ of children hospitalized at the following departments, Neonatal Pathology $(n=89)$, Infant Department $(n=5)$, and Pediatric Surgery $(n=6)$, were selected for the study. Inflammation markers, i.e., white blood cell count, CRP (C-reactive protein) value, platelet count (PLT), procalcitonin index, as well as leading clinical diagnosis, information about the presence of a catheter, intubation, birth weight, date of sample collection or date of admission to the ward, and the presence of resistance mechanisms were the initial criteria for selecting the research group. The samples were collected between 2015 and 2018. These isolates were identified to the species level using classical microbiology identification methods and the biochemical API Staph test (bioMérieux, Poland). The study was approved by the Bioethics Committee of the Jagiellonian University (No. KBET/263/B/2013).

\subsubsection{Antimicrobial Susceptibility Testing}

To determine the drug resistance phenotype, the Kirby-Bauer disk diffusion method was used with the Mueller-Hinton agar (bioMérieux, Poland), 0.5 McFarland inoculum, and the following antibiotics (Oxoid-Argenta, Poland): cefoxitin (30 $\mu \mathrm{g})$, erythromycin $(15 \mu \mathrm{g})$, clindamycin $(2 \mu \mathrm{g})$, gentamicin $(10 \mu \mathrm{g})$, and linezolid $(10 \mu \mathrm{g})$ were used in the study. Zones of inhibition were measured after the growth of bacteria overnight $(18 \pm 2 \mathrm{~h})$ at $35 \pm 2{ }^{\circ} \mathrm{C}$. S. aureus ATCC 29213 was used as the quality control.

In order to identify the methicillin (MRSE) and macrolide, lincosamide, and streptogramin B resistance $\left(\mathrm{MLS}_{\mathrm{B}}\right)$ among the tested strains, cefoxitin $(30 \mu \mathrm{g})$, erythromycin $(15 \mu \mathrm{g})$, and clindamycin $(2 \mu \mathrm{g})$ disks were used.

The MLS $_{B}$ phenotype can take two forms: (1) constitutive (cMLS $S_{B}$ ) or (2) inducible $\left(\mathrm{iMLS}_{\mathrm{B}}\right)$. Strains with the constitutive $\mathrm{MLS}_{\mathrm{B}}$ resistance phenotype $\left(\mathrm{cMLS}_{\mathrm{B}}\right)$ show resistance to erythromycin and clindamycin while strains with the induced $M L S_{B}$ resistance phenotype $\left(\mathrm{iMLS}_{\mathrm{B}}\right.$ ) show resistance to erythromycin and susceptibility to clindamycin with a characteristic D-zone, and strains with $\mathrm{MS}_{\mathrm{B}}$ are resistant to erythromycin and sensitive to clindamycin.

In the case of both an inductive and constitutive mechanism, macrolides, lincosamides, and streptogramins B should not be used in therapy. Detection of the $\mathrm{MS}_{\mathrm{B}}$ mechanism excludes the use of 14- and 15-membered macrolides and streptogramins B.

Susceptibility to vancomycin and teicoplanin was additionally tested in the MRSE strains and the minimal inhibitory concentration (MIC) values were determined by the Etest method (bioMérieux, Poland). A series of twofold dilutions of an antibiotic are incorporated on a plastic carrier strip from which the antibiotic diffuses freely into the agar, creating a diffusion gradient along the length of the strip. After incubation overnight, the MIC is read as the point where the growth inhibition ellipse intersects the MIC scale on the strip.

The results were interpreted according to the European Committee on Antimicrobial Susceptibility Testing (EUCAST) clinical breakpoint tables $2021 \mathrm{v} 11.0$ and EUCAST Disk Diffusion Test Methodology v 9 [38,55].

\subsubsection{Biofilm Detection}

Evaluation of the biofilm-forming capacity was carried out on all the S. epidermidis isolates selected using two different phenotypic methods and the genetic method.

\section{Freeman Method}

The studied strains were cultured on the tryptic soy agar (TSA, bioMérieux, Poland), supplemented with $36 \mathrm{~g} / \mathrm{mL}$ saccharose and $0.8 \mathrm{~g} / \mathrm{L}$ Congo Red (Sigma Aldrich, Poland). After $24 \mathrm{~h}$ of aerobic incubation at $37^{\circ} \mathrm{C}$, the cultures were kept at room temperature for 
another $24 \mathrm{~h}$, and then the colony morphology was determined. A positive result was indicated by black matte or blackish-brown matte colonies, whereas a negative result was recorded when strains developed red mucoid colonies [22]. Reference strains represented by S. epidermidis ATCC 35984 and S. epidermidis ATCC 12228 were used as the positive and negative controls, respectively.

\section{Christensen Method}

One hundred ninety microliters of the brain heart infusion broth (BHI, bioMérieux, Poland) containing $1 \%$ saccharose and $10 \mu \mathrm{L}$ of $18-\mathrm{h}$ bacterial cultures were added to each well of polystyrene 96-well microtiter plates (Nest Scientific Biotechnology, USA). After 48-h incubation, the wells were washed with sterile saline solution and dried at $37^{\circ} \mathrm{C}$ for $2 \mathrm{~h}$. Next, the plates were stained with crystal violet and the biofilm-bound dye was extracted with $96 \%$ ethanol [23]. The extracts were transferred to another 96-well plate followed by optical density (OD) measurements at $600 \mathrm{~nm}$ (Sunrise, Tecan Biotech, Poland). The results were interpreted taking into account the results of optical density (OD) measurements of the biofilm. The experiment was performed in triplicate and repeated three times. The cutoff value (ODc) discriminating biofilm producers from non-biofilm producers was defined as three standard deviations (SD) above the mean OD of the negative control (Staphylococcus epidermidis ATCC 12228). The ODc value was calculated for each microtiter plate separately (Table 7). The abovementioned interpretation of biofilm production was based on the criteria presented by Stepanovic et al. [56].

Table 7. Interpretational criteria for Christensen assay.

\begin{tabular}{cc}
\hline Average OD Value & Biofilm Production \\
\hline OD $\leq$ ODc & Non-biofilm producer \\
ODc $<$ OD $\leq 2 \times$ ODc & Weak biofilm producer \\
$2 \times$ ODc $<$ OD $\leq 4 \times$ ODc & Moderate biofilm producer \\
$4 \times$ ODc $<$ OD & Strong biofilm producer \\
\hline
\end{tabular}

* Optical density cutoff value (ODc) $=$ average OD of the negative control $+3 \times$ standard deviation (SD) of the negative control.

\section{Scanning Fluorescent Microscope}

The biofilm formed in the wells of the microtiter plate (Nest Scientific Biotechnology, USA) by Christensen method was visualized using a scanning fluorescent microscope Leica DMi8 (Leica Microsystems, Wetzlar, Germany). With the SYPRO Ruby Biofilm Matrix Stain, the excitation/emission wavelengths were $450 \mathrm{~nm}$ and $610 \mathrm{~nm}$, respectively. The scanning fluorescent microscope images were analyzed by the image processing software Leica Application Suite (LAS X, Leica Microsystems, Wetzlar, Germany). Biofilms were stained with $200 \mu \mathrm{L}_{\text {FilmTracer }}{ }^{\mathrm{TM}}$ SYPRO ${ }^{\mathrm{TM}}$ Ruby Stain Biofilm Matrix (ThermoFisher Scientific, Figure $7 a, b)$ per each plate well and incubated in the dark for $30 \mathrm{~min}$ at room temperature, then rinsed with distilled water. The preparation of the samples for imaging was performed according to the staining procedure recommended by the manufacturer [57].

\subsection{Genetic Methods}

4.2.1. Identification of the Tested Strains to the Species Level and Detection of Selected Resistance Mechanisms

Genetic analysis included: (1) species identification, (2) detection of the mecA gene (associated with methicillin resistance), and (3) analysis of the presence of the erm, msr, and mef gene families (related to the resistance to macrolides, lincosamides, and streptogramins B).

Bacterial genomic DNA was isolated using the Genomic Mini Kit (A\&A Biotechnology, Poland) according to the manufacturer's protocol. 


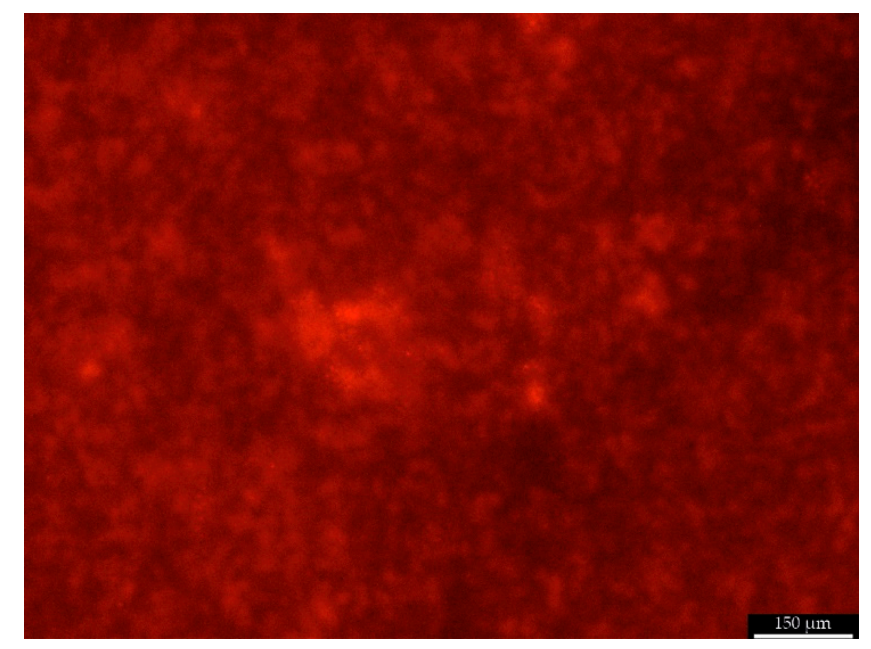

(a)

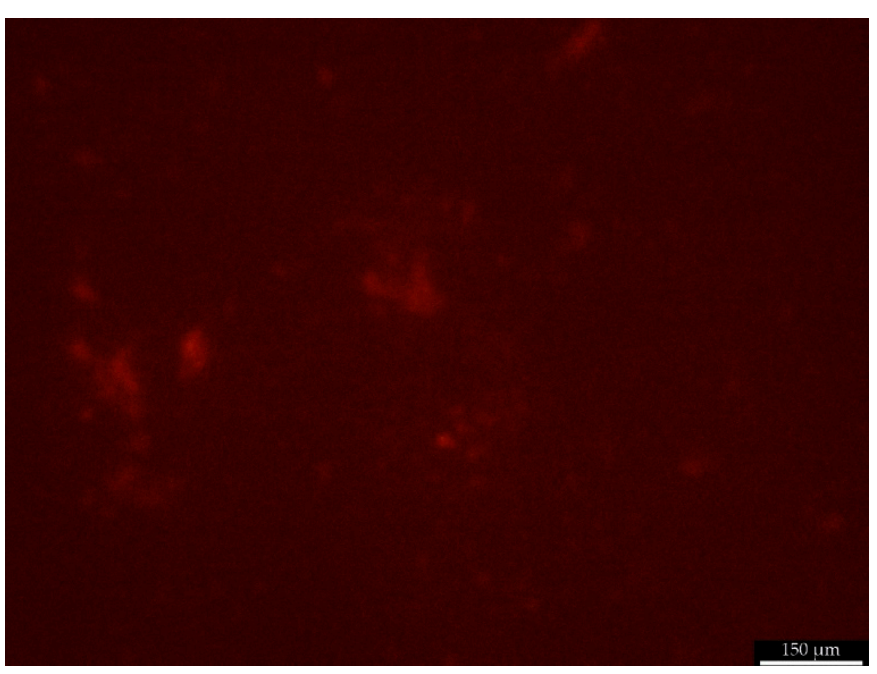

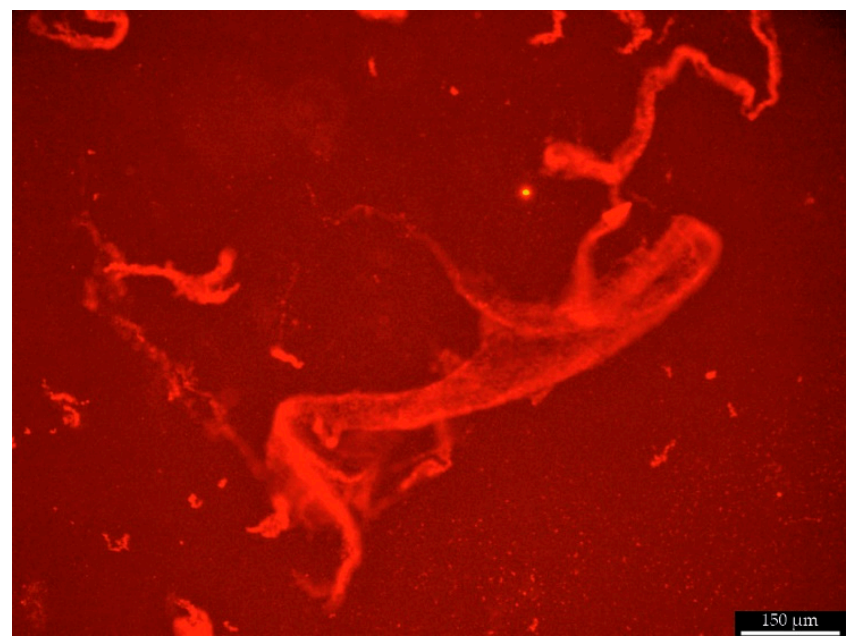

(b)

(c)

Figure 7. Sample photo of the biofilm formed by clinical strain K/12/8915 stained with FilmTracer ${ }^{\text {TM }}$ SYPRO ${ }^{\text {TM }}$ Ruby Stain and visualized using a scanning fluorescent microscope ((a) compact biofilm structure at the bottom of a plate well, (b) extracellular mucus on the biofilm surface, and (c) S. epidermidis ATCC 12228 strain that does not produce a biofilm). Scale bar $=150 \mu \mathrm{m}$.

The next step of the study included the multiplex PCR reaction performed in order to identify the bacterial strains to the species level and to detect the presence of the mec $A$ gene. The following primers presented in Table 8 were used to amplify the fragments specific for S. aureus (SA1, SA2), S. epidermidis (SE1, SE2), S. haemolyticus (SH1, SH2), and the mecA gene (MRS1, MRS2) [20]. DNA amplification was performed using a Biometra T Personal thermocycler (Biometra, Germany) with the following thermal profile: initial denaturation at $94{ }^{\circ} \mathrm{C}$ for $2 \mathrm{~min}$, next 30 cycles of the following profile: denaturation at $94{ }^{\circ} \mathrm{C}$ for $2 \mathrm{~min}$, primer binding at $56^{\circ} \mathrm{C}$ for $1 \mathrm{~min}$, extension at $72{ }^{\circ} \mathrm{C}$ for $1.5 \mathrm{~min}$, and final extension at $72{ }^{\circ} \mathrm{C}$ for $5 \mathrm{~min}$.

The genes encoding macrolide resistance (erm $A, \operatorname{erm} B, \operatorname{erm} C, m s r A$ and $m e f)$ were detected using multiplex PCR under the following conditions: initial denaturation at $94{ }^{\circ} \mathrm{C}$ for $3 \mathrm{~min}, 30$ cycles under the following conditions: $94{ }^{\circ} \mathrm{C}$ for $30 \mathrm{~s}, 55^{\circ} \mathrm{C}$ for $30 \mathrm{~s}, 72{ }^{\circ} \mathrm{C}$ for $2 \mathrm{~min}$, and final extension at $72{ }^{\circ} \mathrm{C}$ for $2 \mathrm{~min}$ [21]. The products of both PCR reactions were detected by electrophoresis on a $2 \%$ agarose gel (MAXIMUS, Polskie Agarozy, Poland) containing ethidium bromide (Sigma Aldrich, USA) performed at the constant voltage of 
$90 \mathrm{~V}$ for $90 \mathrm{~min}$ and were visualized using a UV transilluminator (ECX 20M, Vilber Lourmat, France). The assays described above were conducted using the following reference strains as controls: S. aureus ATCC 25923, S. aureus ATCC 43300, S. epidermidis ATCC 12228, S. aureus ATCC BAA-976, and S. haemolyticus ATCC 29970 (Table 9).

Table 8. The sequences of primers used in the multiplex PCR method performed in order to identify the bacterial species and to detect the mecA gene.

\begin{tabular}{ccc}
\hline Primer & Sequence $\mathbf{( 5}^{\prime} \mathbf{- 3}^{\prime} \mathbf{)}$ & Size of the Product \\
\hline SA1 & AATCTTTGTCGGTACACGATATTCTTCACG & \multirow{2}{*}{$108 \mathrm{bp}$} \\
SA2 & CGTAATGAGATTTCAGTAGATAATACAACA & \multirow{2}{*}{$124 \mathrm{bp}$} \\
\hline SE1 & ATCAAAAAGTTGGCGAACCTTTTCA & \multirow{2}{*}{$271 \mathrm{bp}$} \\
SE2 & CAAAAGAGCGTGGAGAAAAGTATCA & [20] \\
SH1 & GGTCGCTTAGTCGGAACAAT & $154 \mathrm{bp}$ \\
\hline MRS1 & CACGAGCAATCTCATCACCT & \\
\hline MRS2 & TAGAAATGACTGAACGTCCG & TTGCGATCAATGTTACCGTAG \\
\hline
\end{tabular}

Table 9. The sequences of primers used to detect the genetic determinants of macrolide resistance with the multiplex PCR.

\begin{tabular}{ccc}
\hline Primer & Sequence $\mathbf{( 5}^{\prime} \mathbf{- 3}^{\prime} \mathbf{)}$ & Size of the Product \\
\hline ermA1 & TATCTTATCGTTGAGAAGGGATT & $139 \mathrm{bp}$ \\
ermA2 & CTACACTTGGCTTAGGATGAAA & $142 \mathrm{bp}$ \\
$e r m B 1$ & CTATCTGATTGTTGAAGAAGGATT & $190 \mathrm{bp}$ \\
$e r m C 1$ & GTTTACTCTTGGTTTAGGATGAAA & $163 \mathrm{bp}$ \\
erm 2 & CTTGTTGATCACGATAATTTCC & \\
$m s r A 1$ & ATCTTTTAGCAAACCCGTATTC & $348 \mathrm{bp}$ \\
$m e f 1$ & TCCAATCATAGCACAAAATC & \\
$m e f 2$ & AATTCCCTCTATTTGGTGGT & \\
\hline
\end{tabular}

\subsubsection{Detection of Genes Associated with Biofilm Formation}

Detection of the icaADB gene cluster (Table 10) [24] was carried out in a thermocycler (Biometra, Germany) under the following conditions: initial denaturation at $94{ }^{\circ} \mathrm{C}$ for $3 \mathrm{~min}$ followed by 30 cycles of $1 \mathrm{~min}$ denaturation at $94{ }^{\circ} \mathrm{C}$, annealing for $1 \mathrm{~min}$ at $58{ }^{\circ} \mathrm{C}$, and extension for $1 \mathrm{~min}$ at $72{ }^{\circ} \mathrm{C}$ with the final extension step at $72{ }^{\circ} \mathrm{C}$ for $5 \mathrm{~min}$. PCR products were detected by electrophoresis on a $2 \%$ agarose gel (MAXIMUS, Polskie Agarozy, Poland) containing ethidium bromide (Sigma Aldrich, USA). Five microliters of 1000-bp markers and the PCR products were pipetted to each well (DNA Marker 1, A\&A Biotechnology Poland). Electrophoresis was performed at the constant voltage of $90 \mathrm{~V}$ for $60 \mathrm{~min}$ and the results were visualized using a UV transilluminator (ECX 20M, Vilber Lourmat, France). The gels were documented by a Power-Shot G5 (Canon, Japan) digital camera.

Table 10. The sequences of primers used for PCR detection of the genes involved in biofilm formation.

\begin{tabular}{ccc}
\hline Primer & \multicolumn{1}{c}{ Sequence $\left(5^{\prime}-\mathbf{3}^{\prime}\right)$} & Size of the Product \\
\hline$i c a A D B-F$ & TTATCAATGCCGCAGTTGTC & $546 \mathrm{bp}$ \\
$i c a A D B-R$ & GTTTAACGCGAGTGCGCTAT & \\
\hline
\end{tabular}

\subsubsection{Statistical Analysis}

Descriptive statistics were calculated first. Discrete characteristics are expressed as frequency counts and percentages $(n, \%)$. The data were statistically analyzed using the multivariate logistic regression analysis. Multivariate logistic regression models examined 
the impact of resistance mechanisms, resistance to gentamycin, and resistance to teicoplanin using three different biofilms methods (separately). The indicators were marked as significant when the $p$-value (two-sided) was lower than 0.05. All statistical analyses were performed using SPSS Statistics version 26 for Macintosh.

For Christensen method, weak and moderate biofilm producers were analyzed as one group and compared to strong producers because of the fact that the sample size was too small for appropriate statistical analysis. Additionally, we combined two types of resistance mechanisms in one variable with six subgroups.

\section{Conclusions}

Due to the clinical and therapeutic problem of multidrug resistance of Staphylococcus epidermidis strains isolated from the blood of neonates, it is necessary to conduct clinical analyses to determine their ability to produce a biofilm which may pose an unusual mechanism of resistance. Test extension in order to detect a biofilm should be applied in the case of isolation of multidrug-resistant strains which do not constitute contamination of the collected materials and in the case of therapeutic failures. The results of the research indicate the need in the introduction of biofilm detection methods into the routine diagnostic procedures in clinical microbiology. Our study confirmed that Freeman method is a reliable, less time-consuming, and cost-effective biofilm detection assay.

Supplementary Materials: The data that supports the findings of this study are available online at https:/ / www.mdpi.com/article/10.3390/pathogens10070877/s1; Table S1: The results of phenotypic and genetic identification of strains, resistance mechanisms and antibiotics/chemotherapeutic agents with zones of inhibition/MIC values and three methods of biofilm detection.

Author Contributions: Conceptualization, I.S.-K., E.K., and P.N.; methodology, I.S.-K., E.K., and P.N.; investigation, I.S.-K., J.E., J.K., I.S.-S., I.Ż., and B.P.; resources, I.S.-K., E.K., P.N., J.E., M.T., J.K., I.S.-S., and I.Ż.; writing—original draft preparation, I.S.-K., E.K., P.N., and J.E.; writing-review and editing, I.S.-K., E.K., P.N., and J.E.; visualization, I.S.-K., E.K., and P.N.; supervision, E.K.; project administration, I.S.-K. and E.K.; funding acquisition, I.S.-K. and E.K. All authors have read and agreed to the published version of the manuscript.

Funding: This work was financed from the Jagiellonian University Medical College's statutory funds (N42/DBS/000164). This article is also a result of research project No. 2018/31/N/NZ6/03339 financed by the National Science Center, Poland.

Institutional Review Board Statement: Not applicable.

Informed Consent Statement: Not applicable.

Data Availability Statement: Not applicable.

Conflicts of Interest: The authors declare no conflict of interest.

\section{References}

1. Friedrich, A.W. Control of hospital acquired infections and antimicrobial resistance in Europe: the way to go. Wien. Med. Wochenschr. 2019, 169, 25-30. [CrossRef] [PubMed]

2. Becker, K.; Both, A.; Weißelberg, S.; Heilmann, C.; Rohde, H. Emergence of coagulase-negative staphylococci. Expert Rev. Anti-Infective Ther. 2020, 18, 349-366. [CrossRef]

3. Moles, L.; Gómez, M.; Moroder, E.; Bustos, G.; Melgar, A.; Del Campo, R.; Rodríguez, J. Staphylococcus epidermidis in feedings and feces of preterm neonates. PLoS ONE 2020, 15, e0227823. [CrossRef]

4. Wang, L.; Du, K.-N.; Zhao, Y.-L.; Yu, Y.-J.; Sun, L.; Jiang, H.-B. Risk Factors of Nosocomial Infection for Infants in Neonatal Intensive Care Units: A Systematic Review and Meta-Analysis. Med. Sci. Monit. 2019, 25, 8213-8220. [CrossRef]

5. Konstantinidi, A.; Sokou, R.; Panagiotounakou, P.; Lampridou, M.; Parastatidou, S.; Tsantila, K.; Gounari, E.; Gounaris, A.K. Umbilical Venous Catheters and Peripherally Inserted Central Catheters: Are They Equally Safe in VLBW Infants? A NonRandomized Single Center Study. Medicina 2019, 55, 442. [CrossRef]

6. Bhatta, D.R.; Subramanya, S.H.; Hamal, D.; Shrestha, R.; Gauchan, E.; Basnet, S.; Nayak, N.; Gokhale, S. Bacterial contamination of neonatal intensive care units: How safe are the neonates? Antimicrob. Resist. Infect. Control. 2021, 10, 1-6. [CrossRef]

7. Freitas, F.T.D.M.; Viegas, A.P.B.; Romero, G.A.S. Neonatal healthcare-associated infections in Brazil: systematic review and meta-analysis. Arch. Public Health 2021, 79, 1-10. [CrossRef] 
8. Dong, Y.; Speer, C.P.; Glaser, K. Beyond sepsis: Staphylococcus epidermidis is an underestimated but significant contributor to neonatal morbidity. Virulence 2018, 9, 621-633. [CrossRef]

9. França, A.; Gaio, V.; Lopes, N.; Melo, L. Virulence Factors in Coagulase-Negative Staphylococci. Pathogens 2021, 10, 170. [CrossRef] [PubMed]

10. Yong, Y.Y.; Dykes, G.; Choo, W.S. Biofilm formation by staphylococci in health-related environments and recent reports on their control using natural compounds. Crit. Rev. Microbiol. 2019, 45, 201-222. [CrossRef] [PubMed]

11. Kranjec, C.; Angeles, D.M.; Mårli, M.T.; Fernández, L.; García, P.; Kjos, M.; Diep, D. Staphylococcal Biofilms: Challenges and Novel Therapeutic Perspectives. Antibiotics 2021, 10, 131. [CrossRef]

12. Yin, W.; Wang, Y.; Liu, L.; He, J. Biofilms: The Microbial "Protective Clothing" in Extreme Environments. Int. J. Mol. Sci. 2019, 20, 3423. [CrossRef]

13. Shresthar, L.B.; Bhattarai, N.R.; Khanal, B. Comparative evaluation of methods for the detection of biofilm formation in coagulasenegative staphylococci and correlation with antibiogram. Infect. Drug Resist. 2018, 11, 607-613. [CrossRef] [PubMed]

14. Chon, J.-W.; Lee, U.J.; Bensen, R.; West, S.; Paredes, A.; Lim, J.; Khan, S.; Hart, M.E.; Phillips, K.S.; Sung, K. Virulence Characteristics of mecA-Positive Multidrug-Resistant Clinical Coagulase-Negative Staphylococci. Microorganisms 2020, 8, 659. [CrossRef] [PubMed]

15. Fyfe, C.; Grossman, T.H.; Kerstein, K.; Sutcliffe, J. Resistance to Macrolide Antibiotics in Public Health Pathogens. Cold Spring Harb. Perspect. Med. 2016, 6, a025395. [CrossRef] [PubMed]

16. Teodoro, C.R.S.; Mattos, C.S.; Cavalcante, F.S.; Pereira, E.M.; Dos Santos, K.R.N. Characterization of MLSb resistance among Staphylococcus aureus and Staphylococcus epidermidis isolates carrying different SCCmec types. Microbiol. Immunol. 2012, 56, 647-650. [CrossRef]

17. Khashei, R.; Malekzadegan, Y.; Ebrahim-Saraie, H.S.; Razavi, Z. Phenotypic and genotypic characterization of macrolide, lincosamide and streptogramin B resistance among clinical isolates of staphylococci in southwest of Iran. BMC Res. Notes 2018, 11, 711. [CrossRef]

18. Michels, R.; Last, K.; Becker, S.; Papan, C. Update on Coagulase-Negative Staphylococci-What the Clinician Should Know. Microorganisms 2021, 9, 830. [CrossRef] [PubMed]

19. Sánchez, A.; Benito, N.; Rivera, A.; García, L.; Miró, E.; Mur, I.; González, Y.; Gutiérrez, C.; Horcajada, J.; Espinal, P.; et al. Pathogenesis of Staphylococcus epidermidis in prosthetic joint infections: can identification of virulence genes differentiate between infecting and commensal strains? J. Hosp. Infect. 2020, 105, 561-568. [CrossRef]

20. Pereira, E.M.; Schuenck, R.P.; Malvar, K.L.; Iório, N.L.; Matos, P.D.; Olendzki, A.N.; Oelemann, W.M.; Dos Santos, K.R. Staphylococcus aureus, Staphylococcus epidermidis and Staphylococcus haemolyticus: Methicillin-resistant isolates are detected directly in blood cultures by multiplex PCR. Microbiol. Res. 2010, 165, 243-249. [CrossRef]

21. Chaieb, K.; Zmantar, T.; Chehab, O.; Bouchami, O.; Ben Hasen, A.; Mahdouani, K.; Bakhrouf, A. Antibiotic Resistance Genes Detected by Multiplex PCR Assay in Staphylococcus epidermidis Strains Isolated from Dialysis Fluid and Needles in a Dialysis Service. Jpn. J. Infect. Dis. 2007, 60, 183-187. [CrossRef]

22. Freeman, D.J.; Falkiner, F.R.; Keane, C.T. New method for detecting slime production by coagulase negative staphylococci. J. Clin. Pathol. 1989, 42, 872-874. [CrossRef]

23. Christensen, G.D.; A Simpson, W.; Younger, J.J.; Baddour, L.M.; Barrett, F.F.; Melton, D.M.; Beachey, E.H. Adherence of coagulasenegative staphylococci to plastic tissue culture plates: a quantitative model for the adherence of staphylococci to medical devices. J. Clin. Microbiol. 1985, 22, 996-1006. [CrossRef]

24. Ferreira, A.A.; Tette, P.A.S.; Mendonça, R.C.S.; Soares, A.D.S.; De Carvalho, M.M. Detection of exopolysaccharide production and biofilm-related genes in Staphylococcus spp. isolated from a poultry processing plant. Food Sci. Technol. 2014, 34, 710-716. [CrossRef]

25. Jakiel, G.; Wilińska, M.; Bińkowska, M.; Kowal, A.; Rumowska, S.; Ciebiera, M. Late preterm infants-impact of perinatal factors on neonatal results. A clinical study. Ann. Agric. Environ. Med. 2015, 22, 536-541. [CrossRef] [PubMed]

26. Sadkowska-Todys, M.; Zieliński, A.; Czarkowski, M.P. Infectious diseases in Poland in 2013. Prz. Epidemiol. 2015, 69, 329-334.

27. Turlej, A.; Hryniewicz, W.; Empel, J. Staphylococcal Cassette Chromosome mec (SCCmec) Classification and Typing Methods: an Overview. Pol. J. Microbiol. 2011, 60, 95-103. [CrossRef]

28. Brzychczy-Wloch, M.; Borszewska-Kornacka, M.; Gulczyńska, E.; Wojkowska-Mach, J.; Sulik, M.; Grzebyk, M.; Luchter, M.; Heczko, P.B.; Bulanda, M. Prevalence of antibiotic resistance in multi-drug resistant coagulase-negative staphylococci isolated from invasive infection in very low birth weight neonates in two Polish NICUs. Ann. Clin. Microbiol. Antimicrob. 2013, 12, 41. [CrossRef]

29. Al-Mulla, N.A.; Taj-Aldeen, S.J.; Elshafie, S.S.; Janahi, M.; Al-Nasser, A.A.; Chandra, P. Bacterial bloodstream infections and antimicrobial susceptibility pattern in pediatric hematology/oncology patients after anticancer chemotherapy. Infect. Drug Resist. 2014, 7, 289-299. [CrossRef] [PubMed]

30. Najar-Peerayeh, S.; Moghadas, A.J.; Behmanesh, M. Antibiotic Susceptibility and mecA Frequency in Staphylococcus epidermidis, Isolated from Intensive Care Unit Patients. Jundishapur J. Microbiol. 2014, 7, e11188. [CrossRef] [PubMed]

31. Hassoun, A.; Linden, P.K.; Friedman, B. Incidence, prevalence, and management of MRSA bacteremia across patient populationsa review of recent developments in MRSA management and treatment. Crit. Care 2017, 21, 1-10. [CrossRef] 
32. Szczuka, E.; Prawda-Zolotar, J.; Nowakiewicz, M.; Kaznowski, A. Wrażliwość na antybiotyki i zdolność wytwarzania śluzu przez szczepy gronkowców koagulazo-ujemnych. Med. Dosw. Mikrobiol. 2011, 63, 1.

33. Wojtyczka, R.D.; Orlewska, K.; Kępa, M.; Idzik, D.; Dziedzic, A.; Mularz, T.; Krawczyk, M.; Miklasińska, M.; Wąsik, T.J. Biofilm Formation and Antimicrobial Susceptibility of Staphylococcus epidermidis Strains from a Hospital Environment. Int. J. Environ. Res. Public Health 2014, 11, 4619-4633. [CrossRef] [PubMed]

34. Juda, M.; Chudzik-Rzad, B.; Malm, A. The prevalence of genotypes that determine resistance to macrolides, lincosamides, and streptogramins B compared with spiramycin susceptibility among erythromycin-resistant Staphylococcus epidermidis. Mem. Inst. Oswaldo Cruz 2016, 111, 155-160. [CrossRef] [PubMed]

35. Szemraj, M.; Czekaj, T.; Kalisz, J.; Szewczyk, E.M. Differences in distribution of MLS antibiotics resistance genes in clinical isolates of staphylococci belonging to species: S. epidermidis, S. hominis, S. haemolyticus, S. simulans and S. warneri. BMC Microbiol. 2019, 19, 124. [CrossRef] [PubMed]

36. Feßler, A.T.; Wang, Y.; Wu, C.; Schwarz, S. Mobile lincosamide resistance genes in staphylococci. Plasmid 2018, 99, 22-31. [CrossRef]

37. Bialkowska-Hobrzanska, H.; Jaskot, D.; Hammerberg, O. Molecular characterization of the coagulase-negative staphylococcal surface flora of premature neonates. J. Gen. Microbiol. 1993, 139, 2939-2944. [CrossRef]

38. Available online: http://www.korld.edu.pl/spec_rekomendacje-eucast.php (accessed on 28 August 2020).

39. Dzierżanowska, D. Antybiotykoterapia Praktyczna; Alfa Medica Press: Bielsko-Biała, Poland, 2018.

40. Tevell, S.; Claesson, C.; Hellmark, B.; Söderquist, B.; Nilsdotter-Augustinsson, $\AA$. Heterogeneous glycopeptide intermediate Staphylococcus epidermidis isolated from prosthetic joint infections. Eur. J. Clin. Microbiol. Infect. Dis. 2014, 33, 911-917. [CrossRef]

41. Wu, H.; Moser, C.; Wang, H.-Z.; Høiby, N.; Song, Z.-J. Strategies for combating bacterial biofilm infections. Int. J. Oral Sci. 2015, 7, 1-7. [CrossRef]

42. Zheng, Y.; He, L.; Asiamah, T.K.; Otto, M. Colonization of medical devices by staphylococci. Environ. Microbiol. 2018, 20, 3141-3153. [CrossRef]

43. Grzebyk, M.; Brzychczy-Włoch, M.; Piotrowska, A.; Krzyściak, P.; Heczko, P.B.; Bulanda, M. Phenotypic evaluation of hydrophobicity and the ability to produce biofilm in coagulase-negative staphylococci isolated from infected very-low-birthweight new-borns. Med. Dosw. Mikrobiol. 2013, 65, 149-159.

44. Oliveira, A.; Cunha, M.D.L.R. Comparison of methods for the detection of biofilm production in coagulase-negative staphylococci. BMC Res. Notes 2010, 3, 260. [CrossRef] [PubMed]

45. Cafiso, V.; Bertuccio, T.; Santagati, M.; Campanile, F.; Amicosante, G.; Perilli, M.; Selan, L.; Artini, M.; Nicoletti, G.; Stefani, S. Presence of the ica operon in clinical isolates of Staphylococcus epidermidis and its role in biofilm production. Clin. Microbiol. Infect. 2004, 10, 1081-1088. [CrossRef] [PubMed]

46. Mathur, T.; Singhal, S.; Khan, S.; Upadhyay, D.J.; Fatma, T.; Rattan, A. Detection of biofilm formation among the clinical isolates of Staphylococci: An evaluation of three different screening methods. Indian J. Med Microbiol. 2006, 24, 25-29. [CrossRef]

47. Līduma, I.; Tračevska, T.; Bērs, U.; Žileviča, A. Phenotypic and genetic analysis of biofilm formation by Staphylococcus epidermidis. Medicina 2012, 48, 305-309. [CrossRef]

48. Fraiha, R.O.; Pereira, A.P.R.; Brito, E.D.C.A.; Borges, C.L.; Parente, A.F.A.; Perdomo, R.T.; Macedo, M.L.; Weber, S.S. Stress conditions in the host induce persister cells and influence biofilm formation by Staphylococcus epidermidis RP62A. Rev. Soc. Bras. Med. Trop. 2019, 52, e20180001. [CrossRef] [PubMed]

49. Fey, P.D.; E Olson, M. Current concepts in biofilm formation of Staphylococcus epidermidis. Futur. Microbiol. 2010, 5, 917-933. [CrossRef]

50. Büttner, H.; Emack, D.; Erohde, H. Structural basis of Staphylococcus epidermidis biofilm formation: mechanisms and molecular interactions. Front. Cell. Infect. Microbiol. 2015, 5, 14. [CrossRef]

51. Gajewska, J.; Chajecka-Wierzchowska, W. Biofilm Formation Ability and Presence of Adhesion Genes among Coagulase-Negative and Coagulase-Positive Staphylococci Isolates from Raw Cow's Milk. Pathogens 2020, 9, 654. [CrossRef]

52. Del Pozo, J.L. Biofilm-related disease. Expert Rev. Anti-Infective Ther. 2018, 16, 51-65. [CrossRef]

53. Moryl, M. Extracellular matrix as a microbial virulence factor in the development of human diseases. Postęp. Hig. Med. Dośw. 2015, 69, 1485-1498.

54. Pietruczuk-Padzik, A.; Stefańska, J.; Semczuk, K.; Dzierzanowska, D.; Tyski, S. Evaluation of biofilm formation by Staphylococcus aureus isolated from sputum of cystic fibrosis patients. Med. Dosw. Mikrobiol. 2010, 62, 1-8. [PubMed]

55. Available online: https://www.eucast.org/fileadmin/src/media/PDFs/EUCAST_files/Disk_test_documents/2021_manuals/ Manual_v_9.0_EUCAST_Disk_Test_2021.pdf (accessed on 15 June 2021).

56. Stepanović, S.; Vukovic, D.; Dakić, I.; Savić, B.; Švabić-Vlahović, M. A modified microtiter-plate test for quantification of staphylococcal biofilm formation. J. Microbiol. Methods 2000, 40, 175-179. [CrossRef]

57. Available online: https://www.thermofisher.com/document-connect/document-connect.html?url=https://assets.thermofisher. com/TFS-Assets/LSG/manuals/mp10318.pdf (accessed on 15 June 2021). 